Article

\title{
In Vivo Neuropharmacological Potential of Gomphandra tetrandra (Wall.) Sleumer and In-Silico Study against $\beta$-Amyloid Precursor Protein
}

\author{
Md. Saidur Rahman 1,2 ${ }^{1}$, Md. Nazmul Hasan Zilani ${ }^{3}{ }^{-}$, Md. Aminul Islam 1,2, Md. Munaib Hasan ${ }^{3}$,

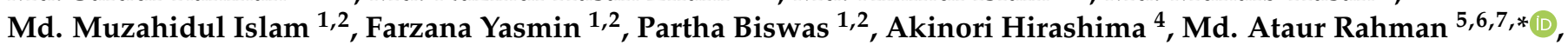 \\ Md. Nazmul Hasan $1,2, * \mathbb{D}$ and Bonglee Kim $6,7, * \mathbb{B}$
}

1 Department of Genetic Engineering and Biotechnology, Faculty of Biological Science and Technology, Jashore University of Science and Technology, Jashore 7408, Bangladesh; saidurriyad24@gmail.com (M.S.R.); aminuljust1996@gmail.com (M.A.I.); muzahidul@just.edu.bd (M.M.I.); farzana.just@gmail.com (F.Y.); partha_160626@just.edu.bd (P.B.)

2 Laboratory of Pharmaceutical Biotechnology and Bioinformatics, Department of Genetic Engineering and Biotechnology, Jashore University of Science and Technology, Jashore 7408, Bangladesh

3 Department of Pharmacy, Faculty of Biological Science and Technology, Jashore University of Science and Technology, Jashore 7408, Bangladesh; zilani.phar@just.edu.bd (M.N.H.Z.); munaib_151010@student.just.edu.bd (M.M.H.)

check for updates

Citation: Rahman, M.S.; Zilani, M.N.H.; Islam, M.A.; Hasan, M.M.; Islam, M.M.; Yasmin, F.; Biswas, P.; Hirashima, A.; Rahman, M.A.; Hasan, M.N.; et al. In Vivo

Neuropharmacological Potential of Gomphandra tetrandra (Wall.) Sleumer and In-Silico Study against $\beta$-Amyloid Precursor Protein. Processes 2021, 9, 1449. https:// doi.org/10.3390/pr9081449

Academic Editors: Ibrahim M. Abu-Reidah and Hoon Kim

Received: 23 July 2021

Accepted: 18 August 2021

Published: 20 August 2021

Publisher's Note: MDPI stays neutral with regard to jurisdictional claims in published maps and institutional affiliations.

Copyright: (c) 2021 by the authors. Licensee MDPI, Basel, Switzerland. This article is an open access article distributed under the terms and conditions of the Creative Commons Attribution (CC BY) license (https:/ / creativecommons.org/licenses/by/ $4.0 /)$.
4 Laboratory of Pesticide Chemistry, Division of Bio-Science and Biotechnology, Faculty of Agriculture, Kyushu University, Fukuoka 812-8581, Japan; ahirasim@agr.kyushu-u.ac.jp

5 Global Biotechnology \& Biomedical Research Network (GBBRN), Department of Biotechnology and Genetic Engineering, Faculty of Biological Sciences, Islamic University, Kushtia 7003, Bangladesh

6 Department of Pathology, College of Korean Medicine, Kyung Hee University, Seoul 02447, Korea

7 Korean Medicine-Based Drug Repositioning Cancer Research Center, College of Korean Medicine, Kyung Hee University, Seoul 02447, Korea

* Correspondence: ataur1981rahman@hotmail.com (M.A.R.); mn.hasan@just.edu.bd (M.N.H.); bongleekim@khu.ac.kr (B.K.)

Abstract: Medicinal plants possess a surplus of novel and biologically active secondary metabolites that are responsible for counteracting diseases. Traditionally, Gomphandra tetrandra (Wall.) Sleumer is used to treat mental disorders. The present research was designed to explore phytochemicals from the ethanol leaf extract of Gomphandra tetrandra (Wall.) Sleumer to identify the potential pharmacophore(s) in the treatment of neurological disorders. The chemical compounds of the experimental plant were identified through GC-MS analysis. In-vitro antioxidant activity was assessed using different methods. Furthermore, in-vivo neurological activity was assessed in Swissalbino mice. Computer-aided analysis was appraised to determine the best-fit phytoconstituent of a total of fifteen identified compounds in the experimental plant extract against beta-amyloid precursor protein. The experimental extract revealed fifteen compounds in GC-MS analysis and the highest content was 9, 12, 15-octadecatrienoic acid $(z, z, z)$. The extract showed potent antioxidant activity in in-vitro assays. Furthermore, in in-vivo neurological assays, the extract disclosed significant $(p<0.05)$ neurological activity. The most favorable phytochemicals as neurological agents were selected via ADMET profiling, and molecular docking was studied with beta-amyloid precursor protein. In the computer-aided study, 1, 5-diphenyl-2h-1, 2, 4-triazoline-3-thione (Pub Chem CID: 2802516) was more active than other identified compounds with strong binding affinity to beta-amyloid precursor protein. The present in vivo and in silico studies revealed neuropharmacological features of G. tetrandra leaf extract as a natural agent against neurological disorders, especially Alzheimer's disease.

Keywords: neurological activity; GC-MS; ADMET profile; molecular docking; beta-amyloid precursor protein; Alzheimer's disease 


\section{Introduction}

The World Health Organization (WHO) approximates that more than a billion people suffer from psychological disorders globally. These include bipolar disorder, traumatic disorders, epilepsy, schizophrenia, Alzheimer's disease, Parkinson's disease, brain tumors, neuro infections, and cerebrovascular disorders like stroke and migraine. Among these diseases, Alzheimer's disease (AD) is prominent in older age groups. It is an advanced neurodegenerative brain disorder that causes structural and functional damage to the brain. Clinically, $\mathrm{AD}$ is characterized by unconscious behavior, memory impairment, lack of emotion, dysfunctional changes in language and speech, fatigue, hallucinations, lack of self-sufficiency, a decline in muscle mass, and dependency on caretakers [1,2]. Physiologically, $\mathrm{AD}$ is caused due to mitochondrial dysfunction, formation of reactive species (oxygen and nitrogen), lipid peroxidation, nitrosative stress, protein aggregation, protein oxidation, amyloidopathy, tauopathies, CREB signaling pathway, GSK-3 hypothesis, DNA damage, depletion of endogenous antioxidant enzymes, proteasome dysfunction, microglial activation, neuroinflammation, neuroepigenetic modification, etc. [1,3-5]. Among these causes, the amyloid hypothesis, neurotransmitter hypothesis, tau propagation hypothesis, and mitochondrial hypothesis were reported to be tested at $22.3 \%, 19.0 \%, 12.7 \%$, and $7.9 \%$, respectively, of all clinical trials up to 2019 [6]. It is noteworthy that it is thought that AD is caused by the pathological accumulation of amyloid-peptides leading to the formation of neurofibrillary tangles and loss of neurons. Most of the current drugs used to treat psychological disorders have obtrusive unwanted effects. This is one of the main obstacles to using these drugs for years. In this perspective, medicinal plants can be a light in the dark. The use of medicinal plants to cure these psychological disorders is seen in ancient scholastic works. Therefore, based on folklore use, an integral part of ethnopharmacology, and scientific evaluation, medicinal plants can serve as a reservoir for the invention of novel bioactive pharmacophores as medicinal plants possess a plethora of novel and biologically active secondary metabolites [7]. Additionally, previous studies have reported the traditional use of Bacopa monnieri (L.) Pennell, Celastrus paniculatus Willd., Centella asiatica (L.) Urban, Clitoria ternatea L., Convolvulus pluricaulis Choisy, Curcuma longa L., Desmodium gangeticum (L.) DC., Evolvulus alsinoides L., Ginkgo biloba L.,Glycyrrhiza glabra L., Melissa officinalis L., Moringa oleifera Lam., Salvia officinalis L., Tinospora cordifolia (Thunb)Miers, Withania somnifera (L.) Dunal etc. in Alzheimer's disease [8-10].

Gomphandra tetrandra (Wall.) Sleumer (Family: Stemonuraceae) is a potential ethnomedicinal evergreen forest shrub available in the hilly regions of Bangladesh. Locally, it is known as Sundalli or Kambuli. It is mostly found in South and Southeast Asia, as well as in Indo-Malaysia and Indochina. In folklore medicine, leaves of G. tetrandra are used to treat epilepsy, convulsions, mental problems, as a tonic, etc. [11]. An alkaloid, camptothecin, has been reported from G. tetrandra [12]. Until now, very few studies have been reported on G. tetrandra. Consequently, this study focused on the identification of bioactive phytochemicals, in-vivo evaluation of neuropharmacological potential, and in-silico study of the beta-amyloid precursor protein responsible for Alzheimer's disease.

\section{Material and Methods}

\subsection{Plant Material Collection and Identification}

The leaves of Gomphandra tetrandra were hoarded from the natural forest of Rangamati, Chittagong, Bangladesh. The sample was collected after getting permission and under the supervision of the forest department. Then, it was identified (DACB-54910) by the Bangladesh National Herbarium, Dhaka, Bangladesh, and an office sample was consigned there.

\subsection{Experimental Animals}

Young Swiss-albino mice (20-25 g weight and six weeks old) were adapted to $24 \pm 1{ }^{\circ} \mathrm{C}$ with $50-70 \%$ relative humidity, a $12 \mathrm{~h}$ light/dark cycle, and fed a typical diet and water accurately. The experimental mice were purchased from the animal research branch of the 
International Center for Diarrheal Disease and Research, Bangladesh (ICDDR, B). All the experimental procedures related to the animal model were performed by the European Community Guideline (EEC directives of 1986; 88/609/EEE) and the ethical standard was approved by the Ethical Review Committee, Faculty of Biological Science and Technology, Jashore University of Science and Technology [Ref: ERC/FBS/JUST/2020-47].

\subsection{Extract Preparation}

The accumulated sample was purified from unwanted materials and washed with distilled water prior to shade drying for 2-3 weeks. Then the dried sample was ground into a coarse powder. About $310 \mathrm{~g}$ of powder was soaked in $950 \mathrm{~mL}$ of ethanol (95\%) with episodic agitation and shaking for ten days. The mixture was filtered using Whatman Grade 1 filter paper (Sigma-Aldrich, St. Louis, MO, USA). Then, using a rotary evaporator (RE-100 PRO, DLAB Scientific Inc., Beijing, China) at $50{ }^{\circ} \mathrm{C}$ and $40 \mathrm{rpm}$, the crude extract was obtained and measured to be $6.53 \mathrm{~g}(2.11 \% \mathrm{w} / \mathrm{w})$.

\subsection{Total Phenol Content}

The total phenol content of the extract was discerned using Folin-Ciocalteau reagent [13]. In total, $5 \mathrm{~mL}$ of $10 \%$ Folin-Ciocalteau reagent was mixed with the extract solution. Then, a $4 \mathrm{~mL} \mathrm{Na} \mathrm{CO}_{3}(7.5 \% \mathrm{w} / \mathrm{v})$ solution was added to the mixture and mixed vigorously by vortexing. Then, the solution was incubated for $30 \mathrm{~min}$ at $40{ }^{\circ} \mathrm{C}$ in an incubator (Mini Incubator, Digi system, DSI-100D, New Taipei city, Taiwan). Finally, the absorbance was measured at $765 \mathrm{~nm}$ (Dynamica Halo DB-20S, Livingston, UK). Gallic acid (500-100 $\mu \mathrm{g} / \mathrm{mL}$ ) was used as a standard to quantify total phenol content. The total phenol content of the extract was calculated and denoted as mg gallic acid equivalent (GAE) per gram of dry extract.

\subsection{Total Flavonoid Content}

Previously described aluminum chloride colorimetric assay [14] was used to estimate the total flavonoids content of the extract. In total, $100 \mu \mathrm{L}$ aluminum chloride $(1 \%)$ and $100 \mu \mathrm{L}$ potassium acetate $(1 \mathrm{M})$ were mixed with extract solution $(1 \mathrm{mg} / \mathrm{mL})$. Then, distilled water $(2.7 \mathrm{~mL})$ was added and vortexed properly. Finally, the absorbance was measured at $415 \mathrm{~nm}$ (Dynamica Halo DB-20S, Livingston, UK). Quercetin $(50-10 \mu \mathrm{g} / \mathrm{mL}$ ) was used as a standard to enumerate total flavonoids content. The total flavonoids content was computed and stated as quercetin equivalent $(\mathrm{QE})$ per gram of dry extract.

\subsection{Gas Chromatography Mass Spectroscopy (GC-MS)}

Gas chromatography-mass spectrometry analysis was carried out with a Clarus ${ }^{\circledR} 690$ gas chromatograph (PerkinElmer, CA, MA, USA) using a column (Elite-35, $30 \mathrm{~m} \times 0.25 \mathrm{~mm}$; PerkinElmer, CA, MA, USA) with $0.25 \mu \mathrm{m}$ film and it was equipped with a Clarus ${ }^{\circledR} \mathrm{SQ}$ $8 \mathrm{C}$ mass spectrophotometer (PerkinElmer, CA, MA, USA). A $1 \mu \mathrm{L}$ sample was injected (splitless mode) and pure helium (99.999\%) was used as a carrier gas at a constant flow rate $(1 \mathrm{~mL} / \mathrm{min})$ for a $40 \mathrm{~min}$ run time. The sample was analyzed in $\mathrm{EI}$ (electron ionization) mode at high energy $(70 \mathrm{eV})$. Though the inlet temperature was constant at $280{ }^{\circ} \mathrm{C}$, column oven temperature was set at $60^{\circ} \mathrm{C}$ (for $0 \mathrm{~min}$ ), raised at $5^{\circ} \mathrm{C}$ per minute to $240{ }^{\circ} \mathrm{C}$ and held for $4 \mathrm{~min}$. The scan time and mass range were $1 \mathrm{~s}$ and $50-600 \mathrm{~m} / \mathrm{z}$, respectively [15]. The sample compounds were identified compared to the National Institute of Standards and Technology (NIST) database.

\subsection{DPPH Free Radical Scavenging Assay}

The antioxidant potential of the extract was estimated by the DPPH scavenging assay [16]. Three milliliters of DPPH $(0.004 \% w / v)$ were mixed to different concentrations $(1024-2 \mu \mathrm{g} / \mathrm{mL}$ ) of the extract solution. After an incubation period of $30 \mathrm{~min}$ (in a dark place at room temperature), the absorbance was taken at $517 \mathrm{~nm}$ (Dynamica Halo DB-20S, Livingston, UK). In this test, ascorbic acid was used as a standard antioxidant for comparison. The DPPH scav- 
enging potential was quantified as: Scavenging $(\%)=\left[1-\left(\mathrm{A}_{\text {Sample }} /\right.\right.$ standard $\left.\left./ A_{\text {control }}\right)\right] \times 100$. From this data, the $\mathrm{IC}_{50}$ value was calculated and compared to ascorbic acid.

\subsection{Ferric Reducing Antioxidant Power (FRAP) Assay}

The ferric reducing antioxidant power of the experimental extract was assessed by FRAP reagent [17] with slight modifications. The FRAP reagent was freshly prepared by mixing acetate buffer (pH-3.6), TPTZ solution $(10 \mathrm{mM})$, and aluminum chloride solution $(20 \mathrm{mM})$ at a ratio of 10:1:1. Then, $3 \mathrm{~mL}$ was mixed with different concentrations $(10-50 \mu \mathrm{g} / \mathrm{mL})$ of extract solution. After $30 \mathrm{~min}$ of incubation at $37^{\circ} \mathrm{C}$, the absorbance was measured at 593 nm (Dynamica Halo DB-20S, Livingston, UK). Ascorbic acid was used as a standard. The reducing power of the extract was denoted as milligrams of ascorbic acid equivalent (AAE) per gram of dry extract.

\subsection{Open Field Test}

An in vivo open field test was conducted on mice based on a reported method [18]. An open field test board is a chessboard-like smooth board with a $0.5 \mathrm{~m}^{2}$ area. It consists of small black and white colored squares with a wall in the border. Twenty mice were randomly assigned into 4 groups containing 5 mice in each. Group-I was treated with distilled water orally at $10 \mathrm{~mL} / \mathrm{kg}$, group-II received diazepam at $1 \mathrm{mg} / \mathrm{kg}$, and group-III and IV were taken the extract at 250 and $500 \mathrm{mg} / \mathrm{kg}$, respectively. Animals were kept in one of the corners of the open field board after administration of the samples. The number of small squares crossed by the mice was counted for 3 min at $0,30,60,90$, and $120 \mathrm{~min}$ from the sample administration time. A room with a calm and quiet environment was used to perform the experiment. The percent movement inhibition of the mice by the extract was calculated as

$$
\% \text { of movement inhibition }=\frac{\mathrm{Mc}-\mathrm{Mt}}{\mathrm{Mc}} \times 100
$$

where Mc indicates the mean number of movements in the control group and Mt denotes the mean number of movements in the test group.

\subsection{Hole Board Test}

The hole board test was performed as stated by the previously reported method [19]. A hole board apparatus is a smooth and plain board $(45 \mathrm{~cm} \times 45 \mathrm{~cm})$ having 16 circular small holes with uniform spacing. In this test, 20 Swiss-albino mice were selected and randomly divided into 4 small groups comprising 5 mice in each group. Group-I and Group-II were considered as the control and the standard groups and received $10 \mathrm{~mL} / \mathrm{kg}$ and $1 \mathrm{mg} / \mathrm{kg}$, respectively. Distilled water was taken as the control and diazepam was used as the standard in this experiment. Both Group-III and Group-IV were the test groups and used to orally administer 250 and $500 \mathrm{mg} / \mathrm{kg}$ of the extract. Each mouse was placed on the hole board apparatus after $30 \mathrm{~min}$ of sample administration to record the number of head dips by individual mice for $10 \mathrm{~min}$. The percent movement inhibition of the mice by the extract was calculated as

$$
\% \text { of movement inhibition }=\frac{\mathrm{Mc}-\mathrm{Mt}}{\mathrm{Mc}} \times 100
$$

where Mc indicates the mean number of head dips in the control group and Mt denotes the mean number of head dips in the test group.

\subsection{Brine Shrimp Lethality Bioassay}

To determine the toxicity of the extract, a brine shrimp lethality test was performed [20]. Firstly, Artemina salina eggs were hatched in an aquarium in simulated sea water. Fluorescent light was applied over the aquarium for $48 \mathrm{~h}$. Ten adult nauplii were added to different concentrations $(1000-31.25 \mu \mathrm{g} / \mathrm{mL})$ of extract using a pasture pipette. The number 
of dead nauplii was examined after $24 \mathrm{~h}$ of the incubation period under a magnifying glass to assess the $\mathrm{LC}_{50}$ value.

\subsection{In-Silico Study}

2.12.1. Development of Phytochemicals Library

A phytochemical library of 15 compounds found via GC-MS analysis of plant extract was created. The names, PubChem CID, molecular weight, and structures of those compounds were developed from the PubChem database.

\subsubsection{Protein Preparation}

For the present study, the non-mutated tertiary (3D) structure of the targeted protein (PDB ID: 1AAP) was downloaded initially in PDB format from the Protein Data Bank. Then, the protein was opened in BIOVA Discovery Studio Visualizer Tool 16.1.0 and energy was minimized after selecting the chain, removing the non-bounded residues, water molecules, and eliminating the unwanted portion of the protein. Finally, the 3D structure of the minimized protein was retrieved in PDB format for further molecular docking studies.

\subsubsection{Active Site Prediction Using CASTp Server and Grid Generation}

In the present study, BIOVA Discovery Studio Visualizer Tool 16.1.0 was used to find the binding site of the desired protein. Moreover, binding pockets over the entire protein were identified using CASTp 3.0. Finally, the receptor grid was generated using the PyRx software.

\subsubsection{Absorption, Distribution, Metabolism and Excretion (ADME), and Toxicity Test}

For developing a molecule as a drug candidate, it is crucial to evaluate the pharmacokinetic properties of phytochemicals, like adsorption, distribution, metabolism, excretion, and toxicity analysis. The Swiss-ADME server was used to estimate the ADME properties of the compounds. Furthermore, of the 15 compounds, only seven that showed the best pharmacokinetic and drug-like properties through Lipinski's rule of violation were selected for molecular docking and further analysis.

\subsubsection{Molecular Docking}

Seven selected compounds after pharmacophore analysis were subjected to molecular docking. In the present study, the PyRx tool was used for molecular docking, which is based on Auto Dock Vina. Resultant compounds with a binding affinity $(\mathrm{kcal} / \mathrm{mol})$ were retrieved and visualized by BIOVA Discovery Studio Visualizer Tool 16.1.0.

\subsection{Statistical Analysis}

All experiments were repeated independently at least three times and results are presented as mean \pm standard deviation (SD). The in vivo data was analyzed by $t$-tests and one-way ANOVA followed by Turkey's test and Dunnett's comparison test using SPSS software version 20.0 (SPSS, Chicago, IL, USA). Differences were considered to be statistically significant when $p<0.05$.

\section{Results}

\subsection{Total Phenol Content}

The total phenol content of the extract was estimated using a calibration curve $\left(\mathrm{Y}=0.00522 \mathrm{X}-0.00290 ; \mathrm{R}^{2}=0.997\right)$ and it was found to be $86.37 \pm 0.73 \mathrm{mg}(\mathrm{GAE}) / \mathrm{g}$ of dried extract.

\subsection{Total Flavonoid Content}

Using the standard quercetin calibration curve $\left(Y=0.007990 X-0.008300 ; R^{2}=0.995\right)$, the total flavonoid content of the extract was computed as $111.17 \pm 1.635 \mathrm{mg}$ quercetin equivalent/g of dry extract. 


\subsection{GCMS Analysis}

In GC-MS analysis, 15 compounds were identified from the experimental extract. Figure 1 represents the distinct GCMS chromatogram.

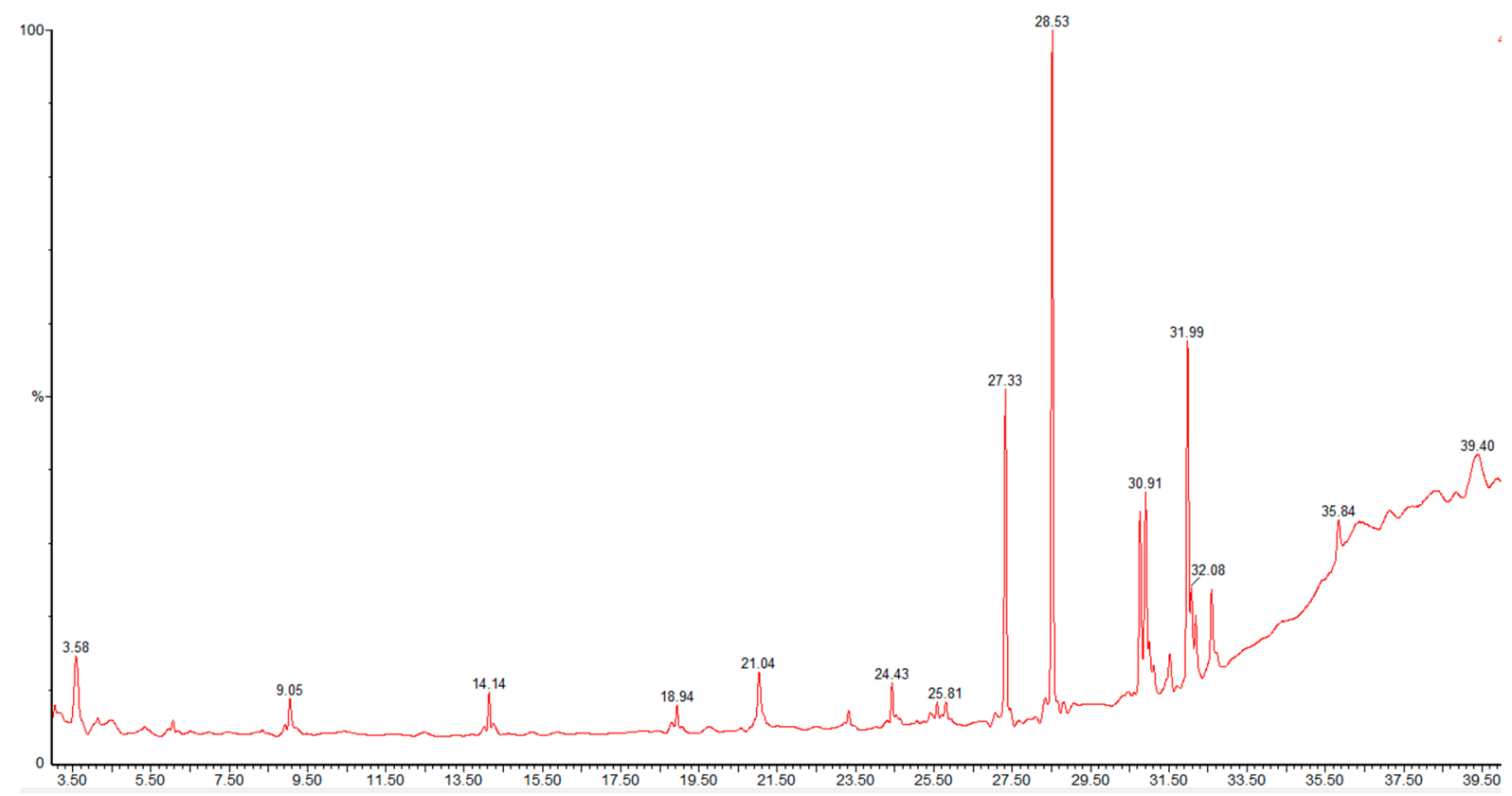

Time

Figure 1. Gas Chromatography mass spectroscopic base chromatogram of G. tetrandra ethanol leaf extract.

The bioactive compounds were represented by their retention time (RT), molecular formula, molecular weight, and peak area (\%) in Table 1 . Among 15 compounds, the four major compounds identified are 9,12,15-octadecatrienoic acid, $(\mathrm{z}, \mathrm{z}, \mathrm{z})(37.86 \%)$, heptadecanoic acid, ethyl ester (25.897\%), 1,2-cyclotadiene (7.625\%), and methyl 11-methyl-dodecanoate (6.287\%). The other compounds are 6-octadecenoic acid (1.43\%), benzene, (1-methylundecyl) $(1.26 \%)$, o-xylene $(0.89 \%)$, benzene, 1,3-dimethyl (0.84\%), 3-n-hexylthiolane, s,s-dioxide $(0.72 \%)$, 1-hexanone, 1 -phenyl $(0.68 \%)$, sulfurous acid, nonyl pentyl ester $(0.59 \%)$, neophytadiene $(0.44 \%), 1,5$-diphenyl-2h-1,2,4-triazoline-3-thione $(0.41 \%)$, chloroacetic acid, tetradecyl ester $(0.33 \%)$, 13-octadecenoic acid, methyl ester $(0.28 \%)$ and heptadecanoic acid, ethyl ester $(0.13 \%)$.

Table 1. Gas Chromatography-Mass spectroscopic data of compounds in G. tetrandra ethanol leaves extract.

\begin{tabular}{|c|c|c|c|c|c|}
\hline $\begin{array}{l}\text { Serial } \\
\text { No. }\end{array}$ & $\begin{array}{l}\text { Retention } \\
\text { Time }\end{array}$ & Name of the Compound & $\begin{array}{l}\text { Molecular } \\
\text { Formula }\end{array}$ & $\begin{array}{c}\text { Molecular } \\
\text { Weight (g/mol) }\end{array}$ & $\%$ Peak Area \\
\hline 1 & 3.58 & O-Xylene & $\mathrm{C}_{8} \mathrm{H}_{10}$ & 106 & 0.8942 \\
\hline 2 & 4.11 & Benzene, 1,3-dimethyl- & $\mathrm{C}_{12} \mathrm{H}_{16}$ & 106 & 0.8402 \\
\hline 3 & 5.45 & Benzene, (1-methylundecyl)- & $\mathrm{C}_{17} \mathrm{H}_{28}$ & 246 & 1.2634 \\
\hline 4 & 6.01 & 1-Hexanone, 1-phenyl- & $\mathrm{C}_{12} \mathrm{H}_{16} \mathrm{O}$ & 176 & 0.6826 \\
\hline 5 & 9.05 & 3-n-Hexylthiolane, s,s-dioxide & $\mathrm{C}_{10} \mathrm{H}_{20} \mathrm{O}_{2} \mathrm{~S}$ & 204 & 0.7248 \\
\hline 6 & 18.94 & Chloroacetic acid, tetradecyl ester & $\mathrm{C}_{16} \mathrm{H}_{31} \mathrm{ClO}_{2}$ & 290 & 0.3253 \\
\hline 7 & 21.04 & Sulfurous acid, nonyl pentyl ester & $\mathrm{C}_{14} \mathrm{H}_{30} \mathrm{O}_{3} \mathrm{~S}$ & 278 & 0.5913 \\
\hline 8 & 24.43 & Neophytadiene & $\mathrm{C}_{20} \mathrm{H}_{38}$ & 278 & 0.4438 \\
\hline 9 & 25.81 & 1,5-Diphenyl-2h-1,2,4-triazoline-3-thione & $\mathrm{C}_{14} \mathrm{H}_{11} \mathrm{~N}_{3} \mathrm{~S}$ & 253 & 0.4150 \\
\hline 10 & 27.33 & Methyl 11-methyl-dodecanoate & $\mathrm{C}_{14} \mathrm{H}_{28} \mathrm{O}_{2}$ & 228 & 6.2876 \\
\hline 11 & 28.53 & Heptadecanoic acid, ethyl ester & $\mathrm{C}_{19} \mathrm{H}_{38} \mathrm{O}_{2}$ & 298 & 25.8970 \\
\hline 12 & 29.83 & 13-Octadecenoic acid, methyl ester & $\mathrm{C}_{19} \mathrm{H}_{36} \mathrm{O}_{2}$ & 296 & 0.2756 \\
\hline 13 & 30.91 & 1,2-Cyclooctadiene & $\mathrm{C}_{8} \mathrm{H}_{12}$ & 108 & 7.6252 \\
\hline 14 & 31.54 & 6-Octadecenoic acid & $\mathrm{C}_{18} \mathrm{H}_{34} \mathrm{O}_{2}$ & 282 & 1.4305 \\
\hline 15 & 31.99 & 9,12,15-Octadecatrienoic acid, $(\mathrm{z}, \mathrm{z}, \mathrm{z})$ - & $\mathrm{C}_{18} \mathrm{H}_{30} \mathrm{O}$ & 278 & 37.8608 \\
\hline
\end{tabular}




\subsection{DPPH Free Radical Scavenging Assay}

Both the extract and the ascorbic acid showed a concentration-dependent DPPH scavenging activity. The $\mathrm{IC}_{50}$ value of the extract was found to be $276.64 \pm 2.91 \mu \mathrm{g} / \mathrm{mL}$ and the standard was $19.02 \pm 1.26 \mu \mathrm{g} / \mathrm{mL}$.

\subsection{Ferric Reducing Antioxidant Power Assay}

The FRAP assay evaluates the antioxidant activity based on the reduction of ferric $\left(\mathrm{Fe}^{3+)}\right.$ to ferrous $\left(\mathrm{Fe}^{2+}\right)$. The FRAP value was calculated using the linear equation $\left(y=0.027 x-0.080, R^{2}=0.993\right)$ obtained from the ascorbic acid standard curve. In this study, ferric reducing capacity was estimated at $90.07 \pm 0.973 \mathrm{mg} / \mathrm{g}$ of ascorbic acid equivalent.

\subsection{Open Field Test}

The extract exhibited a depletion in the movements of mice which was statistically significant $(p<0.05)$ compared to the control. The movement reduction was incessant from the first observation ( $30 \mathrm{~min}$ ) to the final (at $120 \mathrm{~min}$ ) for both doses (250 and $500 \mathrm{mg} / \mathrm{kg}$ ) of the extract. At the final observation time, the movement inhibition by the extract at $250 \mathrm{mg} / \mathrm{kg}$ was $58.33 \%$ and it was higher than that of standard $(42.66 \%)$ at that particular time. However, at $500 \mathrm{mg} / \mathrm{kg}$ dose, the movement inhibition was better than the standard at $90 \mathrm{~min}(50.86 \%)$ and $120 \mathrm{~min}(69.04 \%)$ (Figure 2).

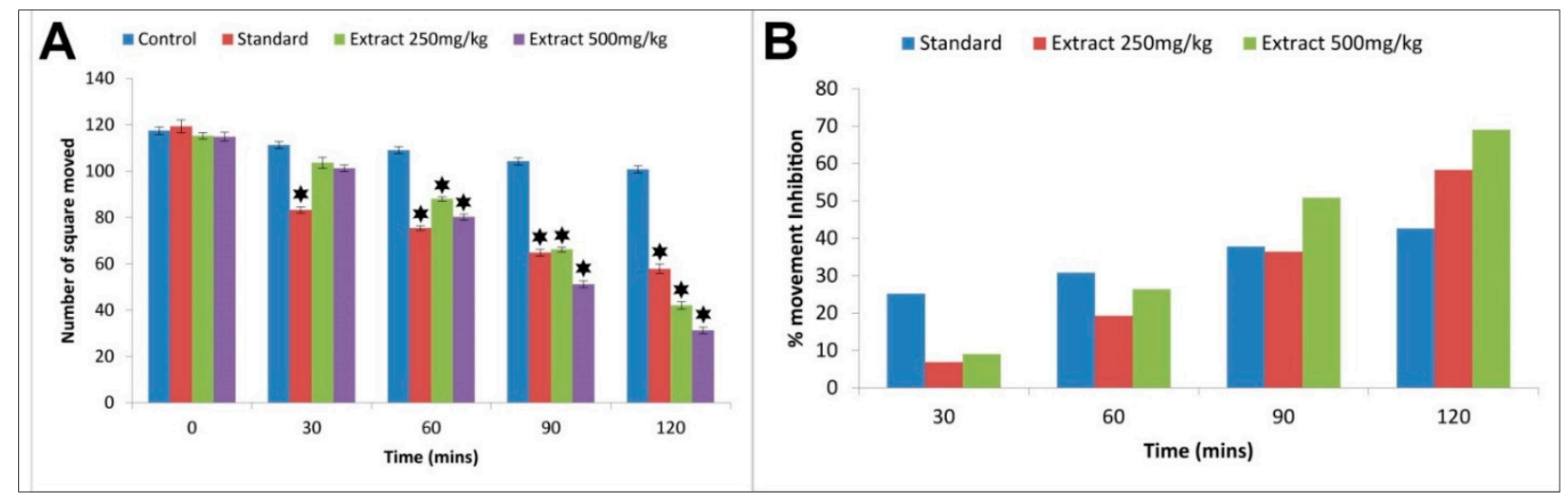

Figure 2. Neuropharmacological activity of G. terandra in open field test. (A) Number of squares moved by mice vs. time, (B) percent movement inhibition of mice with time. Here, values are presented as mean $\pm \operatorname{SD}(n=5) .{ }^{*}$ indicates statistical significance when $p<0.05$.

\subsection{Hole Board Test}

The extract exhibited a significant $(p<0.05)$ abatement in the number of head dips in mice compared to the effect of the control. The percentage of head dipping inhibition was $16.23 \%$ and $28.04 \%$ at 250 and $500 \mathrm{mg} / \mathrm{kg}$ doses of the extract, respectively, while diazepam at $1 \mathrm{mg} / \mathrm{kg}$ showed inhibition of $26.93 \%$ (Figure 3). The extract at $250 \mathrm{mg} / \mathrm{kg}$ body weight showed better head dipping inhibition than the standard.

\subsection{Brine Shrimp Lethality Bioassay}

The estimated $\mathrm{LC}_{50}$ value of the extract was $387.44 \pm 1.46 \mu \mathrm{g} / \mathrm{mL}$ and for the standard, it was $0.91 \pm 0.74 \mu \mathrm{g} / \mathrm{mL}$. The result showed that the extract exhibited little or no cytotoxicity on shrimp larvae.

\subsection{In Silico Study}

\subsubsection{Evaluation of Pharmacokinetic Properties}

Seven compounds out of the 15 fulfilled all the criteria of the ADMET analysis and showed drug-likeness characteristics (Table 2). That is why they have been selected for further molecular docking analysis. These molecules exhibit an extensive excretion rate 
after metabolism in the body. Besides, they also revealed maximum tolerance doses in a range from 0.303 to $1.173 \mathrm{mg} / \mathrm{kg} /$ day (Table 2). Moreover, several toxicological parameters, such as hepatotoxicity and AMES toxicity, were assessed and found to be in an acceptable range.

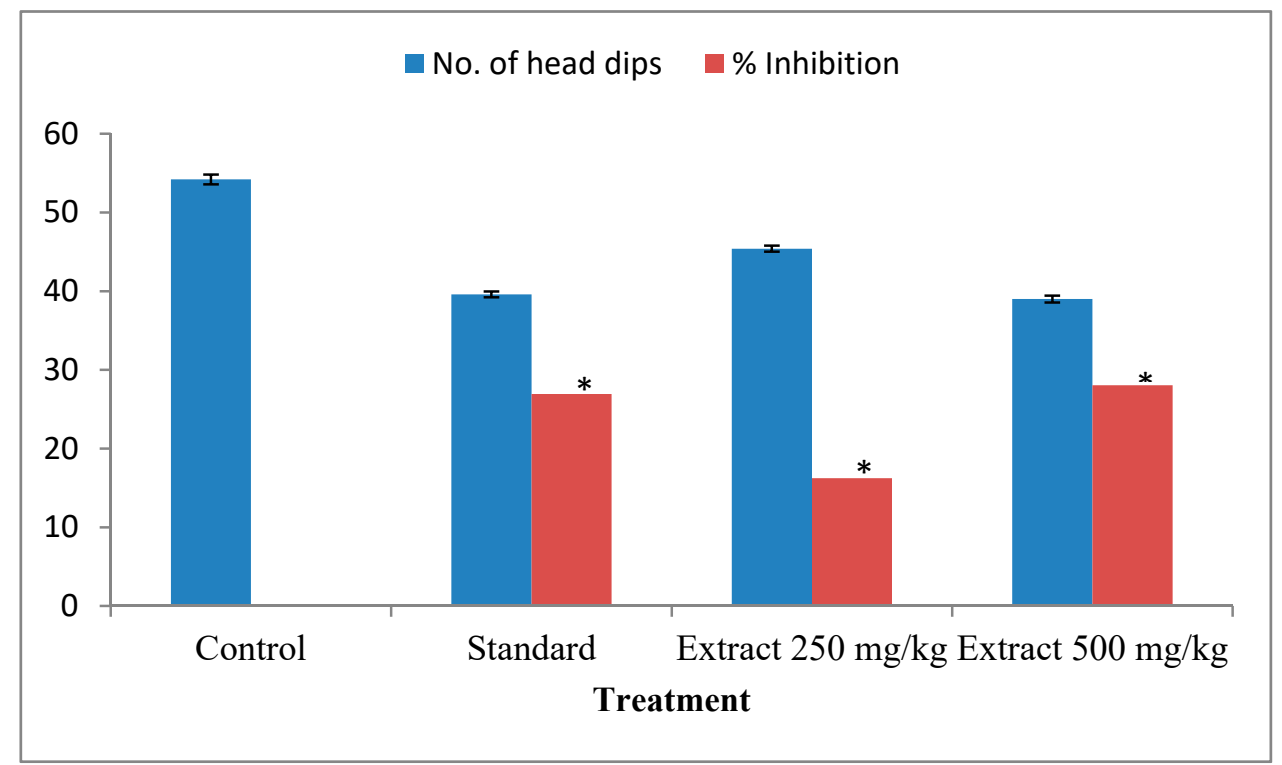

Figure 3. Neurological activity of G. tetrandra in the hole board test (Values are presented as Mean $\pm \mathrm{SD})(n=5),{ }^{*} p<0.05$ compared to control group.

Table 2. The pharmacophore and pharmacokinetic profile of the selected ligand molecules.

\begin{tabular}{|c|c|c|c|c|c|c|c|c|c|c|c|c|c|}
\hline Ligands Name & MW & NHA & NHD & $\log P$ & NRB & GIA & LD50 & BBB & HT & AT & MTD & NLV & DL \\
\hline $\begin{array}{l}\text { Rivastigmine } \\
\text { (control) }\end{array}$ & 250.34 & 3 & 0 & 3.21 & 6 & High & 3.402 & Yes & No & No & 0.382 & No & Yes \\
\hline O-Xylene & 106.16 & 0 & 0 & 2.303 & 0 & Low & 1.841 & Yes & No & No & 0.921 & No & Yes \\
\hline 1-Hexanone, 1-phenyl- & 176.25 & 1 & 0 & 3.449 & 5 & High & 1.655 & Yes & No & No & 1.173 & No & Yes \\
\hline $\begin{array}{l}\text { 3-n-Hexylthiolane, } \\
\text { S,S-dioxide }\end{array}$ & 204.33 & 2 & 0 & 2.391 & 5 & High & 2.033 & Yes & No & No & 0.393 & No & Yes \\
\hline $\begin{array}{l}\text { Sulfurous acid, nonyl } \\
\text { pentyl ester }\end{array}$ & 278.45 & 3 & 0 & 4.539 & 12 & High & 1.98 & Yes & No & No & 0.653 & No & Yes \\
\hline $\begin{array}{l}\text { 1,5-Diphenyl-2h-1,2,4- } \\
\text { triazoline-3-thione }\end{array}$ & 253.32 & 1 & 1 & 3.596 & 2 & High & 2.81 & Yes & No & No & 0.926 & No & Yes \\
\hline $\begin{array}{c}\text { Methyl } \\
\text { 11-methyl-dodecanoate }\end{array}$ & 228.37 & 2 & 0 & 4.326 & 11 & High & 1.6 & Yes & No & No & 0.303 & No & Yes \\
\hline 1,2-Cyclooctadiene & 108.18 & 0 & 0 & 2.661 & 0 & Low & 2.043 & Yes & No & No & 0.852 & No & Yes \\
\hline
\end{tabular}

MW-molecular weight (g/mol); NHA-No. of hydrogen bond acceptor; NHD—No. of hydrogen bond donor; LogP—Predicted octanol/water partition coefficient; NRB-Number of Rotatable Bond; GIA-Gastro-Intestinal absorption (\% absorbed); LD50Oral rat acute toxicity; BBB-Blood-Brain Barrier; HT-Hepatotoxicity; AT-AMES toxicity; MTD-Maximum tolerated dose for humans (log mg/kg/day); NLV—Number of Lipinski's Violation; DL—Drug Likeness.

\subsubsection{Molecular Docking of the Phytochemicals in the Predicted Ligand-Binding Pocket}

Basically, molecular docking is used to understand the biomolecular interactions of the desired compound. Structure-based drug design also takes advantage of this technique. In our study, the top five probable binding pockets in beta-amyloid precursor protein, 1AAP, according to CASTp 3.0 software, were identified (Table 3 ). The software measured the volume and surface areas (SA) of the desired protein and provided the binding pocket volume and areas (Table 3). 
Table 3. Predicted top five ligand-binding pockets according to CASTp.

\begin{tabular}{ccccc}
\hline Serial No. & Pocket ID & Area $\left(\AA^{\mathbf{2}}\right)$ & Volume $\left(\AA^{\mathbf{3}}\right)$ & Pocket Amino Acids \\
\hline 1 & 1 & 40.093 & 18.554 & TRP 21, TRP 22, CYS 30, PHE 45, TRP 47, GLU 48, GLU 49, \\
CYS 55, GLU 56
\end{tabular}

\subsubsection{Molecular Docking Studies}

The beta-amyloid precursor protein (1AAP) has two chains, A and B. A receptor grid with box diameter $\mathrm{X}=17.7, \mathrm{Y}=-17.40, \mathrm{Z}=18.54$ was prepared for the $\mathrm{B}$ chain. The compounds that passed in the ADME and toxicity analysis were studied in the PyRx tool. Among them, only the compound CID2802516 showed the highest binding affinity of $-5.5 \mathrm{Kcal} / \mathrm{mol}$. Besides, the compounds CID70337 and CID543842 showed a binding affinity of $-4.2 \mathrm{Kcal} / \mathrm{mol}$ that was equal to the control ligand CID $77991(-4.2 \mathrm{kcal} / \mathrm{mol})$ (Table 4).

Table 4. The binding affinity of interested ligands with the targeted protein macromolecule and comprehensive intermolecular interactions.

\begin{tabular}{|c|c|c|c|}
\hline \multirow{2}{*}{$\begin{array}{l}\text { Ligands Name } \\
\text { (PubChem CID) }\end{array}$} & \multirow{2}{*}{$\begin{array}{c}\text { Binding } \\
\text { Affinity (Kcal/mol) }\end{array}$} & \multicolumn{2}{|c|}{ Amino Acid Involved Interaction } \\
\hline & & Hydrogen Bond Interaction & Hydrophobic Bonds Interaction \\
\hline $\begin{array}{l}\text { Rivastigmine } \\
\quad(77991)\end{array}$ & -4.2 & THR47 (3.13 A); ASP46 (3.01 ̊̊) & CYS55, GLU48, GLU49, and PHE45 \\
\hline O-Xylene (7237) & -4.0 & No H-bond & $\begin{array}{l}\text { CYS30, CYS55, GLU48, GLU49, } \\
\text { PHE45, and THR47 }\end{array}$ \\
\hline 1-Hexanone, 1-phenyl- (70337) & -4.2 & No H-bond & $\begin{array}{l}\text { ASP46, CYS30, CYS55, GLU48, } \\
\text { GLU49, PHE45 and THR47 }\end{array}$ \\
\hline 3-n-Hexylthiolane,s,s-dioxide (543842) & -4.2 & ASP46 (3.03Å); THR47 (2.86 ̊) & $\begin{array}{l}\text { CYS30, CYS55, GLU48, GLU49, } \\
\text { and PHE45 }\end{array}$ \\
\hline Sulfurous acid, nonyl pentyl ester (572661) & -3.5 & No H-bond & $\begin{array}{l}\text { CYS30, CYS55, GLU48, PHE45 } \\
\text { and THR47 }\end{array}$ \\
\hline $\begin{array}{l}\text { 1,5-Diphenyl-2h-1,2,4-triazoline-3-thione } \\
\text { (2802516) }\end{array}$ & -5.5 & GLU49 (3.04 ̊) & $\begin{array}{c}\text { ASP46, CYS30, CYS55, GLU48, PHE45 } \\
\text { and THR47 }\end{array}$ \\
\hline Methyl 11-methyl-dodecanoate (4065233) & -3.6 & GLY56 (3.34 Å) & $\begin{array}{l}\text { CYS30, CYS55, GLU48, PHE45 } \\
\text { and THR47 }\end{array}$ \\
\hline 1,2-Cyclooctadiene (641048) & -3.8 & $\begin{array}{c}\text { GLY56 N:O1 }(2.91 \AA) \text { and } \\
\text { N:O2 }(3.06 \AA)\end{array}$ & $\begin{array}{c}\text { CYS30, CYS55, GLU48, GLU49, LYS29, } \\
\text { and PHE45 }\end{array}$ \\
\hline
\end{tabular}

\subsubsection{Interpretation of Protein-Ligand Interactions}

The Java-based software Ligplot+ V 2.2 was used to identify the hydrogen bond and hydrophobic bond interactions of the protein-ligand complexes. The control drug Rivastigmine (CID: 77991) showed two hydrogen bonds (THR47 (3.13 ̊); ASP46 (3.01 ^)) and four hydrophobic bonds (CYS55, GLU48, GLU49, and PHE45) with the desired protein (Figure 5). Among the selected phytochemicals, 3-n-hexylthiolane, s,s-dioxide (CID: 543842) and, 1,2-cyclooctadiene (CID: 641048) displayed a maximum of two hydrogen bonds and more than four hydrophobic bonds, respectively. Each of the compounds 1,5-diphenyl-2h1,2,4-triazoline-3-thione (CID: 2802516), and methyl 11-methyl-dodecanoate (CID: 4065233) bound with only one hydrogen bond, but the former had six and the latter had five hydrophobic interactions with the protein. Besides, the rest of the compounds did not have any hydrogen bond interactions but had some hydrophobic bonds (Table 4). 

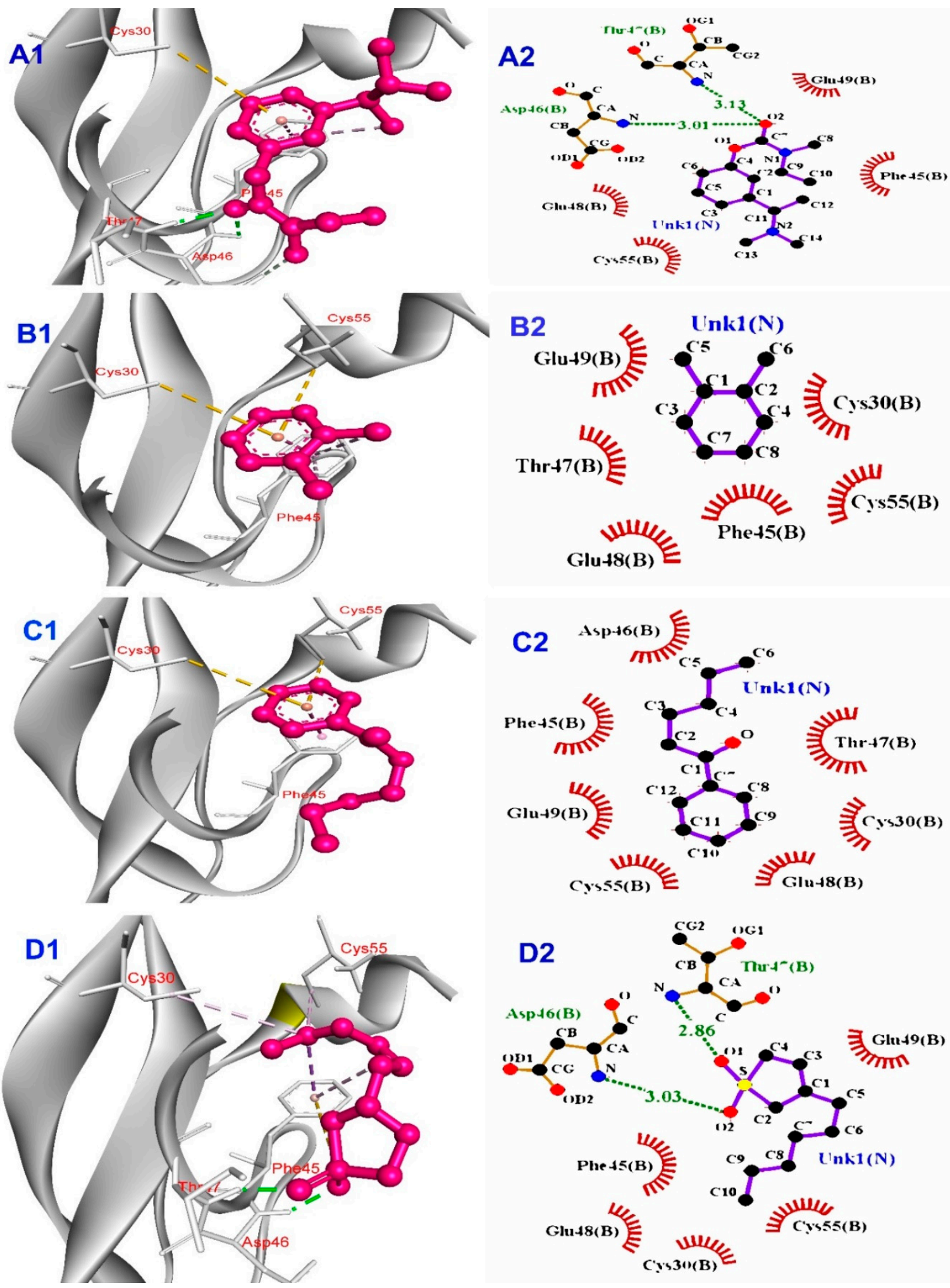

Figure 4. Cont. 

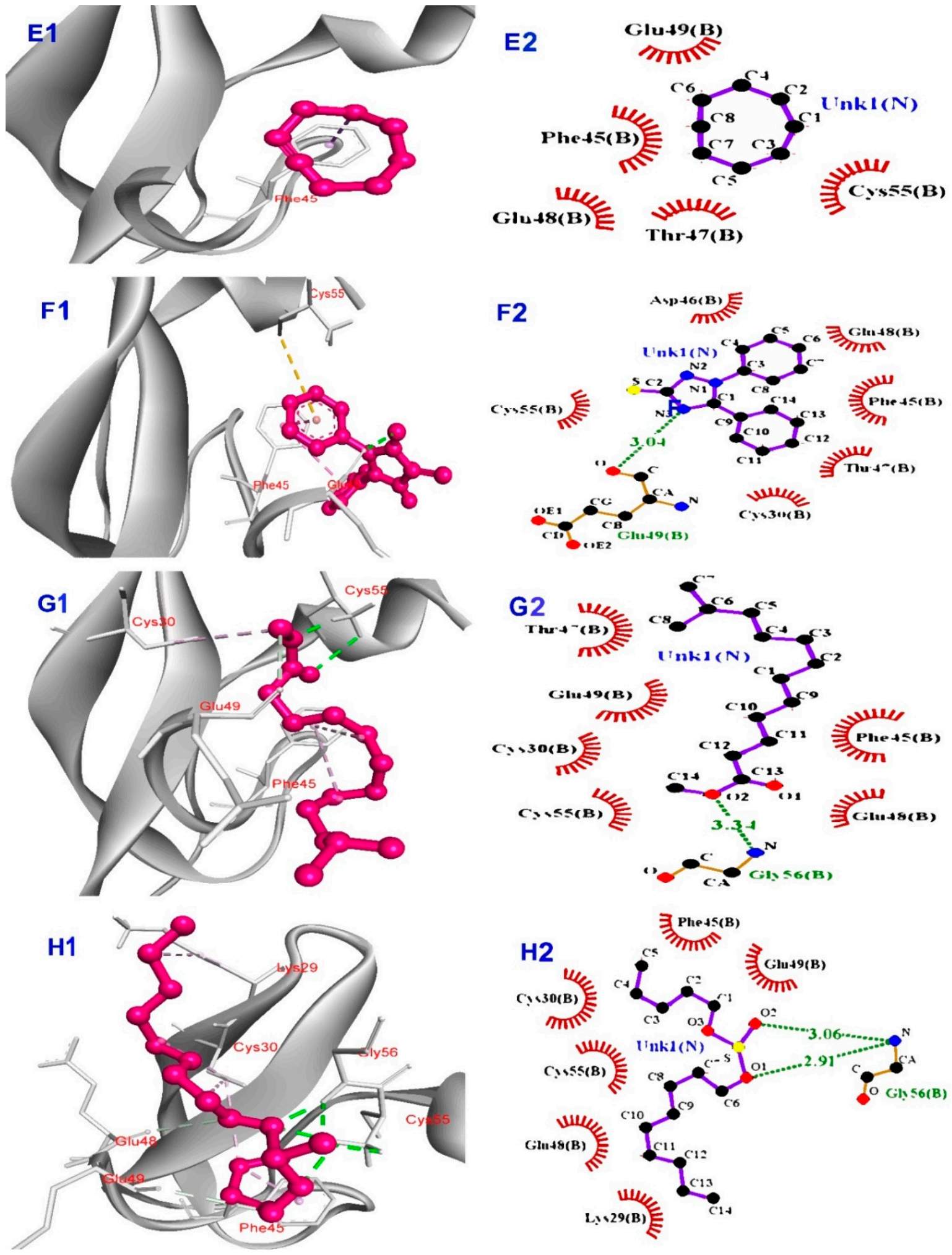

Figure 5. Binding of phytochemicals with the targeted protein (1AAP). Here, the left side indicates a 3D structure, and the right side indicates a 2D structure of ligand-beta-amyloid precursor protein-binding complexes. In the 3D structure, ligand molecules were represented in pink color with a ball and stick model and binding amino acids by letters and a number format which are red in color. In the 2D structure, hydrogen bonding interactions are shown by the olive dotted green line and hydrophobic interactions with the nearest amino acid residues in the red spike. (A) Control drug Rivastigmine; (B) O-Xylene; (C) 1-Hexanone, 1-phenyl; (D) 3-n-Hexylthiolane, s,s-dioxide; (E) Sulfurous acid, nonyl pentyl ester; (F) 1,5-Diphenyl-2h-1,2,4-triazoline-3-thione; (G) Methyl 11-methyl-dodecanoate; (H) 1,2-Cyclooctadiene. 


\section{Discussion}

Ethno-medicinal plants have served as a convenient and efficient source of medicine since ancient times. The popularity of traditional medicine is growing at a startling pace in the developing nations of the world as well as in developed countries for fulfilling basic healthcare purposes [21]. It has been estimated by WHO that one-fourth of modern medicines are prepared from plants that had prior traditional uses [22]. Despite living in the present period of synthetic medicine, research-based drug discovery from ethnomedicine is significantly successful to a large extent.

The open field and hole board tests are very convenient and paramount methods for determining the neurological potential of medicinal plant extracts [23]. In these experiments, the presence of agents with sedative properties will reduce movements and interrupt in the interest of the new milieu. The present experimental extract at 250 and $500 \mathrm{mg} / \mathrm{kg}$ unveiled a significant inhibition of locomotion which caused a gradual reduction in movement in mice compared to the control (Figure 2). The sedative action was first noticed at $30 \mathrm{~min}$ and continued until the last observation period $(120 \mathrm{~min})$. The headdipping behavior of animals in the hole board test is directly related to their emotional state [24]. From our present study, it was evident that the extract had a significant $(p<0.05)$ CNS depressant effect at 250 and $500 \mathrm{mg} / \mathrm{kg}$ (Figure 3). The neuropharmacological activity of the extract could be associated with the compounds distinguished by GC-MS profiling. As the major identified bioactive constituent of the extract, 9,12,15-octadecatrienoic acid, $(z, z, z)$, was reported to exert psychotropic effects [25]. Nevertheless, further isolation of bioactive compounds and in-depth study is required to reveal the mechanism of action of these compounds beyond their neurological effects.

Neurons are predominantly susceptible to oxidative damage owing to their high dependence on oxygen consumption, copious polyunsaturated fatty acids in their membrane, and an enfeebled antioxidant defense mechanism [26,27]. Progressively, it damages neuron structure and impairs neuron function, ultimately causing the development of neurodegenerative disorders. ROS-induced oxidative stress is a vital factor in the pathogenesis of $\mathrm{AD}$ as it causes the accumulation and deposition of amyloid peptides, hyperphosphorylation of tau protein, modulation of JNK/MAPK stress-activated protein kinase pathways, and oxidation of functional biomolecules [3,28-30]. Therefore, phytochemicals with antioxidant activity, through reduction of oxidative damage, may play a vital role in treating AD. The GCMS identified phytochemicals of the extract 9,12,15octadecadtrienoic acid (z,z,z) [31]; heptadecanoic acid, ethyl ester [32]; chloroacetic acid, tetradecyl ester [33]; neophytadiene [34] as having antioxidant activity. Therefore, plantbased therapies that target the relationship between oxidative stress and neurodegeneration at the cellular and molecular level may improve treatment and drug development efforts. In this regard, G. tetrandra can be a source of pharmacophore (s) for that particular purpose.

Nowadays, computer-aided drug design (CADD) is a buzzword across the world to identify drug candidates from diverse sources [35]. Another tremendous screening approach is ADMET profiling, which analyses the molecular weight, lipophilicity, number of hydrogen acceptors and donors, various types of toxicity, and so on. Pharmacokinetic and pharmacophore analysis give extra advantages in predicting the appropriate drug compounds, and Table 3 shows the properties that are important for drug discovery. All the compounds showed drug-like properties and most of the phytochemicals displayed high intestinal absorption rates, but two were low. Toxicity is harmful to the body and most of the toxicity tests on an animal model are expensive and time-consuming [36]. A considerable range of $\mathrm{LD}_{50}$ values were found and that means the toxicity level of the bioactive compounds was low and other toxicity levels like hepatotoxicity and AMES toxicity levels were zero. The blood-brain barrier (BBB) is an important layer that prevents different types of solutes from entering the nervous system. To be a neurological drug, any compound needs to cross BBB [37]. Table 2 showed that all the compounds have the ability to cross the BBB. Furthermore, each and every compound exhibited drug-like characteristics and did not show any Lipinski rule violations. 
Molecular docking is a process that reveals the best binding affinity with minimal energy of protein-ligand complexes. In molecular docking studies, the lowest binding energy refers to the best binding affinity of a ligand to a targeted protein [38]. According to the present study, one compound named 1,5-diphenyl-2h-1,2,4-triazoline-3-thione (CID: 2802516) has shown a higher binding affinity $(-5.5 \mathrm{Kcal} / \mathrm{mol})$ than the control rivastigmine $(-4.2 \mathrm{Kcal} / \mathrm{mol})$. On the other hand, two ligands, 1-hexanone, 1-phenyl- (CID: 70337), and 3-n-hexylthiolane, s,s-dioxide (CID: 543842) have displayed the same docking score $(-4.2 \mathrm{Kcal} / \mathrm{mol})$ as the control drug. Lower binding affinity than control has been obtained by the rest of the compounds and all the data is mentioned in Table 4 . Hence, chemical analysis, in vivo neurological activity assessment, and in silico studies exposed the evidence of folklore use of $G$. tetrandra in mental disorders.

\section{Conclusions}

The current study has divulged the neurological effect of $G$. tetrandra extract in in vivo open field and hole board tests. Besides, among the GCMS identified compounds, 1,5-diphenyl-2h-1,2,4-triazoline-3-thione (Pub Chem CID: 2802516) showed the better interaction with $\beta$-amyloid precursor protein. Furthermore, no toxicity was found for the extract in both the brine shrimp lethality bioassay and in silico study data. Hence, both experimental and computational studies revealed the effectiveness of G. tetrandra in neurological disorders, especially in Alzheimer's disease. It is recommended to isolate bioactive phytochemicals and to explicate the mechanistic pathway for preventing neurological disorders.

Author Contributions: Conceptualization: M.N.H.Z.; Methodology: M.S.R., M.M.I., F.Y.; Software: M.A.I., M.M.H., P.B.; Formal analysis: M.S.R., M.N.H.Z., M.N.H.; Data curation: M.S.R., M.N.H.Z., M.A.I.; Writing-original draft preparation: M.N.H.Z., M.S.R., M.A.I.; Writing-review and editing: M.N.H., A.H., M.A.R.; Supervision: M.N.H.Z., M.N.H.; Funding acquisition: M.N.H., B.K. All authors have read and agreed to the published version of the manuscript.

Funding: This research was supported by Basic Science Research Program through the National Research Foundation of Korea (NRF) funded by the Ministry of Education (NRF-2020R1I1A2066868), the National Research Foundation of Korea (NRF) grant funded by the Korean government (MSIT) (No. 2020R1A5A2019413). The research project was also supported by a grant from the Jashore University of Science and Technology (Grant JUST/Research Cell/FoBST-03-/2020-21).

Institutional Review Board Statement: Not applicable.

Informed Consent Statement: Not applicable.

Data Availability Statement: Not applicable.

Acknowledgments: Authors are grateful to the authorities of the department of genetic engineering and biotechnology and the department of pharmacy, Jashore University of Science and Technology for providing excellent working facilities.

Conflicts of Interest: The authors declare that they have no competing interests.

\section{List of Abbreviations:}

AD: Alzheimer's disease; ROS: Reactive Oxygen Species; CREB: cAMP Response Element-Binding Protein; GSK-3: Glycogen Synthase Kinase-3; GAE: Gallic Acid Equivalent; QE: Quercetin Equivalent; GCMS: Gas Chromatography-Mass Spectroscopy; DPPH: 2,2 diphenyl-1-picrylhydrazyle; FRAP: Ferric Reducing Antioxidant Power; b.w: Body Weight; ADME: Absorption, distribution, metabolism, and excretion; APP: Beta-amyloid Precursor Protein; CNS: Central Nervous System; A $\beta$ : Beta-amyloid; JNK/MAPK: c-Jun $\mathrm{N}$-terminal Kinase of Mitogen-activated Protein Kinase family; CADD: Computer-Aided Drug Design; BBB: Blood-Brain Barrier.

\section{References}

1. Guo, T.; Zhang, D.; Zeng, Y.; Huang, T.Y.; Xu, H.; Zhao, Y. Molecular and cellular mechanisms underlying the pathogenesis of Alzheimer's disease. Mol. Neurodegener. 2020, 15, 1-37. [CrossRef] 
2. Siddappaji, K.K.; Gopal, S. Molecular mechanisms in Alzheimer's disease and the impact of physical exercise with advancements in therapeutic approaches. AIMS Neurosci. 2021, 8, 357-389. [CrossRef]

3. Chen, X.; Drew, J.; Berney, W.; Lei, W. Neuroprotective Natural Products for Alzheimer's Disease. Cells 2021, 10, 1309. [CrossRef]

4. Sharma, P.; Srivastava, P.; Seth, A.; Tripathi, P.N.; Banerjee, A.G.; Shrivastava, S.K. Comprehensive review of mechanisms of pathogenesis involved in Alzheimer's disease and potential therapeutic strategies. Prog. Neurobiol. 2019, 174, 53-89. [CrossRef]

5. Magalingam, K.B.; Radhakrishnan, A.; Ping, N.S.; Haleagrahara, N. Current Concepts of Neurodegenerative Mechanisms in Alzheimer's Disease. BioMed Res. Int. 2018, 2018, 3740461. [CrossRef]

6. Liu, P.-P.; Xie, Y.; Meng, X.-Y.; Kang, J.-S. History and progress of hypotheses and clinical trials for Alzheimer's disease. Signal Transduct. Target. Ther. 2019, 4, 29. [CrossRef] [PubMed]

7. Rahman, M.S.; Zilani, M.N.H.; Islam, M.A.; Hasan, M.M.; Islam, M.M.; Yasmin, F.; Biswas, P.; Hirashima, A.; Rahman, M.A.; Hasan, M.N. In vivo Neuropharmacological Potential of Gomphandra tetrandra (Wall.) Sleumer and in-silico Study against $\beta$-Amyloid Precursor Protein. Preprints 2021, 2021070564. [CrossRef]

8. Mehla, J.; Gupta, P.; Pahuja, M.; Diwan, D.; Diksha, D. Indian Medicinal Herbs and Formulations for Alzheimer's Disease, from Traditional Knowledge to Scientific Assessment. Brain Sci. 2020, 10, 964. [CrossRef]

9. Roy, A. Role of medicinal plants against Alzheimer's disease. Int. J. Complement. Altern. Med. 2018, 11, 1. [CrossRef]

10. Jivad, N.; Rabiei, Z. A review study on medicinal plants used in the treatment of learning and memory impairments. Asian Pac. J. Trop. Biomed. 2014, 4, 780-789. [CrossRef]

11. Uddin, S.N. Traditional Uses of Ethnomedicinal Plants of the Chittagong Hill Tracts; Bangladesh National Herbarium: Dhaka, Bangladesh, 2006.

12. Ramesha, B.; Suma, H.; Senthilkumar, U.; Priti, V.; Ravikanth, G.; Vasudeva, R.; Kumar, T.S.; Ganeshaiah, K.; Shaanker, R.U. New plant sources of the anti-cancer alkaloid, camptothecine from the Icacinaceae taxa, India. Phytomedicine 2013, 20, 521-527. [CrossRef]

13. Zilani, N.H.; Sultana, T.; Rahman, S.M.A.; Anisuzzman, M.; Islam, A.; Shilpi, J.A.; Hossain, G. Chemical composition and pharmacological activities of Pisum sativum. BMC Complement. Altern. Med. 2017, 17, 171. [CrossRef]

14. Devequi-Nunes, D.; Machado, B.A.S.; Barreto, G.A.; Rebouças Silva, J.; da Silva, D.F.; da Rocha, J.L.C.; Brandão, H.N.; Borges, V.M. Umsza-Guez, M.A. Chemical characterization and bioactivity of Trichosanthes dioica edible shoot extract. Orient. Pharm. Exp. Med. 2018, 18, 167-175.

15. Rahman, S.; Hossain, R.; Saikot, F.K.; Rahman, S.M.; Saha, S.K.; Hong, J.; Kim, K.-H. Insights into the in vitro germicidal activities of Acalypha indica. Anal. Sci. Technol. 2017, 30, 26-31. [CrossRef]

16. Hossain, M.G.; Zilani, N.H.; Islam, A.; Khushi, S.S.; Shilpi, J.A.; Rahman, M. Analgesic and antioxidant activities of Colocasia fallax. Orient. Pharm. Exp. Med. 2015, 15, 4.

17. Hmidani, A.; Bouhlali, E.D.T.; Ajebli, M.; Khouya, T.; Benlyas, M.; Alem, C. In vitro investigation of antioxidant and antihemolytic activities of three Lamiaceae species from Morocco. Beni-Suef Univ. J. Basic Appl. Sci. 2021, 10, 1-8. [CrossRef]

18. Anisuzzman, M.; Hasan, M.; Acharzo, A.K.; Das, A.K.; Rahman, S. In Vivo and In Vitro Evaluation of Pharmacological Potentials of Secondary Bioactive Metabolites of Dalbergia candenatensis Leaves. Evid.-Based Complement. Altern. Med. 2017, 2017, 1-10. [CrossRef]

19. Hafiz, W.; Zilani, N.H.; Sultana, N.A.; Isalm, M.; Anisuzzman, M.; Hossain, G. Neuropharmacological potential of Ceriscoides turgida (Roxb.) leaf and root in mice. Clin. Phytoscience 2019, 5, 5. [CrossRef]

20. Sarkar, K.K.; Rahman, M.; Shahriar, A.A.E.; Mitra, T.; Golder, M.; Zilani, N.H.; Biswas, B. Comparative neuropharmacological and Cytotoxic profiles of Alstonia scholaris (L.) and Mimusops elengi (L.) leaves. Adv. Tradit. Med. 2020, 1-8. [CrossRef]

21. Park, Y.L.; Canaway, R. Integrating Traditional and Complementary Medicine with National Healthcare Systems for Universal Health Coverage in Asia and the Western Pacific. Health Syst. Reform 2019, 5, 24-31. [CrossRef]

22. Yuan, H.; Ma, Q.; Ye, L.; Piao, G. The traditional medicine and modern medicine from natural products. Molecules 2016, $21,559$. [CrossRef] [PubMed]

23. Moniruzzaman, M.; Rahman, A.; Ferdous, A. Evaluation of Sedative and Hypnotic Activity of Ethanolic Extract of Scoparia dulcis Linn. Evid.-Based Complement. Altern. Med. 2015, 2015, 873954. [CrossRef]

24. Rath, M.; Bhattacharya, A.; Rath, K.; Santra, S.; Ghosh, G.; Nanda, B.B. A Comprehensive Study of the Neuropharmacological Profile of Methanol Leaf Extract of Aloe vera and Identification of Associated Neuroprotective Compounds through Gas chromatography-mass spectrometry Analysis. Indian J. Pharm. Sci. 2020, 82, 996-1005. [CrossRef]

25. Olivia, N.U.; Goodness, U.C.; Obinna, O.M. Phytochemical profiling and GC-MS analysis of aqueous methanol fraction of Hibiscus asper leaves. Future J. Pharm. Sci. 2021, 7, 59. [CrossRef]

26. Liu, Z.; Ren, Z.; Zhang, J.; Chuang, C.-C.; Kandaswamy, E.; Zhou, T.; Zuo, L. Role of ROS and Nutritional Antioxidants in Human Diseases. Front. Physiol. 2018, 9, 477. [CrossRef]

27. Liu, Z.; Zhou, T.; Ziegler, A.C.; Dimitrion, P.; Zuo, L. Oxidative Stress in Neurodegenerative Diseases: From Molecular Mechanisms to Clinical Applications. Oxid. Med. Cell. Longev. 2017, 2017, 2525967. [CrossRef] [PubMed]

28. Fracassi, A.; Marcatti, M.; Zolochevska, O.; Tabor, N.; Woltjer, R.; Moreno, S.; Taglialatela, G. Oxidative Damage and Antioxidant Response in Frontal Cortex of Demented and Nondemented Individuals with Alzheimer's Neuropathology. J. Neurosci. 2021, 41, 538-554. [CrossRef] 
29. Sharifi-Rad, M.; Kumar, N.A.; Zucca, P.; Varoni, E.M.; Dini, L.; Panzarini, E.; Rajkovic, J.; Fokou, P.V.T.; Azzini, E.; Peluso, I.; et al. Lifestyle, Oxidative Stress, and Antioxidants: Back and Forth in the Pathophysiology of Chronic Diseases. Front. Physiol. 2020, 11, 694. [CrossRef]

30. Cenini, G.; Lloret, A.; Cascella, R. Oxidative Stress in Neurodegenerative Diseases: From a Mitochondrial Point of View. Oxid. Med. Cell. Longev. 2019, 2019, 2105607. [CrossRef]

31. Kim, B.-R.; Kim, H.M.; Jin, C.H.; Kang, S.-Y.; Kim, J.-B.; Jeon, Y.G.; Park, K.Y.; Lee, I.-S.; Han, A.-R. Composition and Antioxidant Activities of Volatile Organic Compounds in Radiation-Bred Coreopsis Cultivars. Plants 2020, 9, 717. [CrossRef]

32. Vats, S.; Gupta, T. Evaluation of bioactive compounds and antioxidant potential of hydroethanolic extract of Moringa oleifera Lam. from Rajasthan, India. Physiol. Mol. Biol. Plants 2017, 23, 239-248. [CrossRef] [PubMed]

33. Wang, J.; Zhang, H.; Zheng, X.; Liu, R.; Zong, W. In vitro toxicity and molecular interacting mechanisms of chloroacetic acid to catalase. Ecotoxicol. Environ. Saf. 2020, 189, 109981. [CrossRef]

34. Simoh, S.; Shin, S.; Abd Rahim, F.; Zainal, M.A.A.; Malaysiana, A.J.S. Comparative Analysis of Metabolites and Antioxidant Potentials from Different Plant Parts of Curcuma aeruginosa Roxb. Sains Malays. 2018, 47, 3031-3041. [CrossRef]

35. Gurung, A.B.; Ali, M.A.; Lee, J.; Farah, M.A.; Al-Anazi, K.M. An Updated Review of Computer-Aided Drug Design and Its Application to COVID-19. BioMed Res. Int. 2021, 2021, 8853056. [CrossRef]

36. Samad, A.; Ahammad, F.; Nain, Z.; Alam, R.; Imon, R.R.; Hasan, M.; Rahman, S. Designing a multi-epitope vaccine against SARS-CoV-2: An immunoinformatics approach. J. Biomol. Struct. Dyn. 2020, 1-17. [CrossRef] [PubMed]

37. Daina, A.; Michielin, O.; Zoete, V. SwissADME: A free web tool to evaluate pharmacokinetics, drug-likeness and medicinal chemistry friendliness of small molecules. Sci. Rep. 2017, 7, 42717. [CrossRef]

38. Basu, A.; Sarkar, A.; Maulik, U. Molecular docking study of potential phytochemicals and their effects on the complex of SARS-CoV2 spike protein and human ACE2. Sci. Rep. 2020, 10, 17699. [CrossRef] 